\title{
Is There a Wage Premium for Returning Irish Migrants?*
}

\author{
ALAN BARRETT \\ PHILIP J. O'CONNELL \\ The Economic and Social Research Institute, Dublin
}

\begin{abstract}
Higher rates of economic growth in recent years have led I reland from being a country characterised by emigration to one where population inflows have become an important issue. This paper contains an analysis of one element of the current inflow. Drawing on data collected in 1998 on over 800 I rish individuals who had graduated from I rish colleges in 1992, we compare the wages of returned migrants with the wages of those who stayed in I reland. In a recent paper, it has been argued that returned migrants accumulate skills and competencies while away that are rewarded on return to the home country. We find support for this argument for men. On average, returning males earn 10 per cent more than men who stayed in I reland, controlling for a range of factors. However, men who say that they originally migrated for labour-related reasons earn 15 per cent more. No wage premium is found for female returning migrants relative to female stayers.
\end{abstract}

\section{INTRODUCTION}

E or most of its modern history, a dominant feature of I reland's economic and social life has been emigration. A stark illustration of this point can be found in the following two data points: in 1841 the population of what is now the Republic of Ireland was 6.5 million; in 1961 it was 2.8 million. The

* The authors would like to acknowledge the comments of Denis Conniffe, Christian Dustmann and Rob Euwals, members of the TSER group on Labour Demand, Education and the Dynamics of Social Exclusion and two anonymous referees. The research was conducted under the EU'S TSER programme, grant no. SOE2-CT97-3052. 
1950s was a particularly bad decade from the perspective of population decline. The annual average rate of net outward migration was 14.1 per thousand, which amounted to a net loss of over 400,000 people between 1951 and 1961 from a population of around 3 million. Given that the outflow was the result of economic stagnation, the government responded in the late 1950s and early 1960s by beginning the process of the modernisation of the Irish economy. This was pursued through policies such as trade liberalisation and the attraction of foreign direct investment. In the 1960s and 1970s, the modernisation policies began to lift the economic stagnation of the earlier decades. The annual average rate of net outflow fell to 4.6 per thousand between 1961 and 1971; in the 1970s, the outflow was reversed and I reland experienced net inflows of 3.2 per thousand per annum between 1971 and $1981 .^{1}$

Many of those in the inflow of the 1970s were former emigrants returning and so in principle the issue under consideration in this paper could have been studied twenty years ago. To understand why this and other immigrationrelated issues did not become part of the research agenda in Ireland, it is necessary to take note of the economic and migration experience of the 1980s. With the return of a weak economic performance, net outflows resumed. Between 1981 and 1991, the rate of net outward migration was 5.9 per thousand; in such a context it is not surprising that the brief period of net inflows in the 1970s did not generate any volume of research.

In the 1990s I reland is enjoying an exceptionally strong economic performance, with growth rates between 1994 and 1999 averaging 7.5 per cent (CSO, 1999). This has generated new net inflows; in the years ended April 1998 and 1999, the rate averaged over 5 per thousand. This inflow is made up partly of I rish emigrants returning and partly of non-I rish immigrants. Given the projected continued growth of the Irish economy, it is likely that the net inflows will continue. In order to understand how the inflows will impact upon the I rish economy, it is important that immigration-related issues begin to be explored in I reland, just as they have been elsewhere for many years.

This paper represents one effort to generate some insights into the nature of the immigration currently affecting I reland. The precise focus of the paper is on people who graduated from I rish colleges in 1992 who have lived outside I reland for at least six months since graduating but who have now returned to I reland to work. By using a dataset which includes information on these "returners" and information on others who remained in I reland since graduation it is possible to compare the wages of "stayers" and "returners" in

1. For more on the economics of I reland's migratory history, see Ó'Gráda and Walsh (1994); for a study focusing on the 1980s experience see NESC (1991). 
1998 and to ask if there is a wage premium for returning I rish migrants.

The paper is structured as follows. In the next section, we discuss some reasons why we might expect the earnings of returning migrants to differ from the earnings of those who never leave their home country. We then go on to briefly discuss the characteristics of recent Irish emigrants and returning migrants, as a lead-in to our description of the data used in the analysis. We then present the results of our analysis. As differences in results by gender emerge, we look more closely at the stated migration motives of the men and women in the sample. We then summarise and offer some conclusions.

\section{REASONS FOR RETURN MIGRATION}

Given the standard economic approach to modelling the migration decision, return migration might be viewed as an irrational pursuit. The standard model, as applied by Borjas (1987) and others, sees individuals comparing their expected lifetime earnings in their present and alternative locations and, adjusting for the cost of migration, moving to (or remaining) where their lifetime earnings will be maximised. In a sense, the costs of migration can be viewed as an investment, with the wage advantage being the return on this investment. By returning to the original location, migrants will not be able to reap the full return.

By introducing additional considerations into the standard model of migration, it is possible to model return migration as an economically rational decision or set of decisions (for example, see Stark, 1991). For example, if an individual puts a higher value on consumption in the home country relative to the host, he might be prepared to move to earn more for a period of time and then to return to spend the additional earnings in the home country. Migration could also be seen as an information gathering exercise. The individual will have imperfect information about opportunities elsewhere. In this case migration can be seen in a job search context; if after searching the individual realises they will be better off at home they will return.

Another motivation for return migration was originally proposed by Dustmann (1997) and has recently been explored further by Co, Gang and Yun (2000); it is their view that we will focus on here. Dustmann introduced the notion that working away from home can be part of the human capital accumulation process. By being exposed to different approaches to technical or management matters, emigrants may pick up skills and competencies that are then rewarded once they return to their home countries. Those who never left will then be observed to earn less relative to the return migrants, controlling for a range of factors. Co, Gang and Yun test the hypothesis with data on 
Hungarians. They find that return migrants do indeed earn a wage premium relative to those who stayed. The premium varies according to which countries the migrants had worked in. In addition, the size of the premium was sensitive to selection corrections, a point we will return to below.

While the story told by Dustmann (1997) is plausible, we would add some considerations. First, while some may migrate for "investment" purposes in an effort to add to their human capital, it is also possible that some migrate for largely "consumption" reasons. By this we mean that some may go and work abroad mainly out of an interest in seeing the world or experiencing different cultures. In this case, while those who remain at home may be accumulating additional human capital through work experience, the migrants may not be doing so, especially if they are working in casual jobs whose only purpose is to support the migrant while travelling. If this story is true, we would expect to see return migrants earning less than stayers at least soon after their return.

A second consideration relates to a signalling story of wage determination as opposed to a human capital story. It could be that returning migrants will be seen to earn more because employers take working abroad as a signal of higher productivity. Employers may believe that migrants have shown initiative and independence by going away and so may be willing to pay a premium to hire people with these perceived desirable qualities.

Finally, a self-selection story can also be told. If people who migrate are highly motivated risk-takers, it could be that any observed link between wages and migration is simply reflecting higher earnings for unobserved characteristics.

To summarise, there are reasons for believing that returning migrants will earn more than those who stay because: (a) they have accumulated additional human capital while away; (b) employers take time away as a signal for higher productivity; (c) those who migrate may have unobservable characteristics (such as initiative) which also lead them to be more productive.

It is, however, possible to reverse each of these stories and to suggest that returning migrants might be observed earning less than stayers. For example, their time away may have been for reasons of consumption and little or no human capital may have been accumulated during their time away. It may be that employers take migration and return as being a negative signal. It may also be that returners have unobservable characteristics (such as being fickle) which lead them to be less productive. Finally, if the timing of a return is related to family-formation or other such decisions, individuals may initially accept lower wages on return.

\section{IRISH EMIGRANTS AND RETURN MIGRANTS}


Table 1: Educational Profile of Return Migrants and Non-Migrants by Age Category (Row percentages Shown)

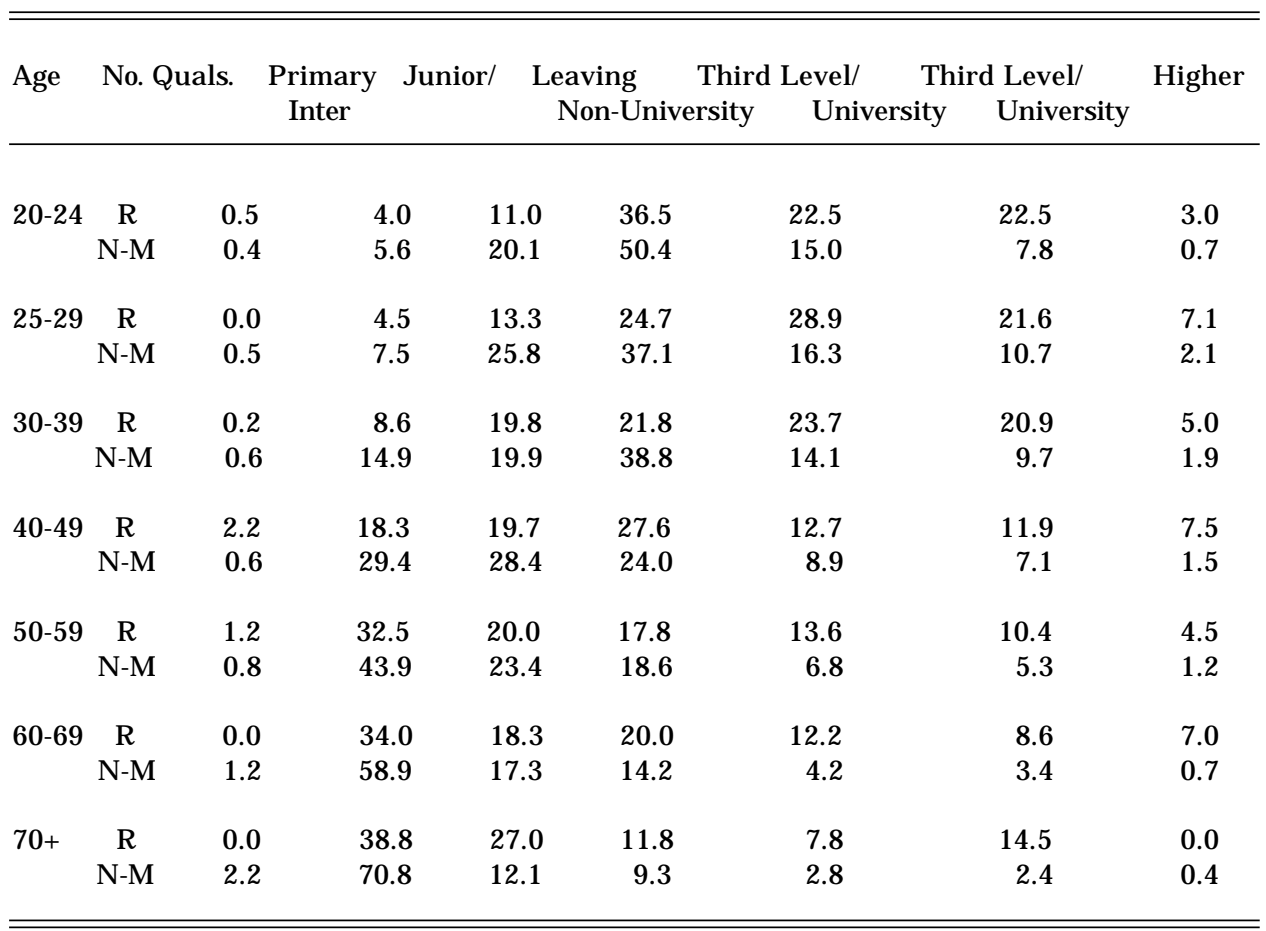

Source: Labour Force Surveys 1994, 1995 and 1996.

$\mathrm{R}=$ return migrants, defined as Irish nationals who were born in Ireland but who were not resident in Ireland twelve months previously; $\mathrm{N}-\mathrm{M}=$ non-migrants, defined as Irish nationals who were born in I reland who were resident in I reland twelve months previously. The percentages are based on 1,400 return migrants and 265,655 non-migrants.

No Quals $=$ no educational qualifications.

Primary $=$ completed primary.

$\mathrm{J}$ unior/I nter = a state exam taken approximately half way through second level schooling.

Leaving = state exam taken at the end of second level schooling.

Third Level/non-university = typically diploma and certificate courses in

Regional Technical Colleges and the Institutes of Technology.

Third level/university and higher university are self-explanatory.

Note: As almost 80 per cent of the return migrants are in the first three age categories, greater attention should be focused on the proportions in the upper part of the table. 
Before describing the data used in the analysis below, we will briefly consider the characteristics of I rish emigrants and return migrants. Up until the 1980s, I rish emigrants were typically unskilled. The main reason for this was the low level of educational attainment in general and the greater likelihood of the more educated remaining in Ireland. In the 1980s, this feature of I rish emigrants was reversed and the outflow began to be more educated. This can be explained partly by the rising level of educational attainment but also by the increased likelihood of the more skilled emigrating relative to the less skilled. This in turn has been partly explained by changes in the relative generosity of the Irish social welfare system and the relative severity of the taxation system in the 1980s (NESC, 1991).

Given that the outflow of the 1980s was relatively more educated than both previous generations of emigrants and the domestic population, it would be expected that the returning migrants in the 1990s, who would be drawn from this pool, would also have relatively high levels of education attainment. Barrett and Trace (1998) have shown this to be the case. Table 1 (which is taken from Barrett and Trace) compares the educational profiles of migrants who have returned within twelve months of the survey date and the profile of the resident population aggregated over the years 1994 to 1996. The resident population includes people who returned earlier than twelve months previously so we do not get a strict comparison of returners and stayers. Nonetheless, the figures are interesting.

It can be seen in the table that the resident population has relatively higher proportions in the lower levels of the educational distribution while relatively higher proportions of the return migrants are found in the upper sections of the distribution. Barrett and Trace go on to present evidence that the returning migrants are not just more highly educated than the resident population; they also appear to be more highly educated than the group who emigrated in the 1980s.

\section{THE DATA}

In the preceding section, we have shown that returning I rish migrants are heavily drawn from the pool of third level graduates. For this reason, the data that we use are particularly useful for the analysis of return migration into I reland.

The data come from a survey which was sponsored by the Irish Department of Education and Science and which sought to generate information on the labour market experiences of graduates from I rish third level colleges. Drawing on the records of colleges, a random sample of 3,400 
individuals who graduated in 1992 was generated. In the summer of 1998, questionnaires were mailed to these individuals. About 1,350 responses were obtained. The comparatively low response rate of 40 per cent was largely due to the difficulty in tracing individuals using university administrative records of addresses which in some cases were over eight years old. We checked for biases in responses by comparing our sample with figures from the Higher Education Authority. We found that there was no bias as regards migration (HEA, 1993), gender and area of study (HEA, 1994). Further details of the survey and the sample can be found in Gash and O'Connell (2000) which contains a comprehensive analysis of the sample.

The questionnaire asked for information on a range of individual characteristics and labour market matters. Hence, we have information on age, sex and level of educational attainment. We also have information on labour market experience and gross wages.

As regards migration, the respondents were asked if they "have ever lived outside Ireland for a continuous period of more than six months since completing third level education?" (italics included in the questionnaire); they were also asked if they are currently resident in Ireland. Combining these questions we define "returners" as those who answered "yes" to both and we define "stayers" as those who are resident in I reland but who have not lived away for more than six months.

\section{$\checkmark$ RESULTS}

We now present the results of our analysis. We included in our analysis Irish nationals who said that their "present usual situation with regard to employment" was working for payment or profit. After eliminating other observations because of missing values, we were left with 670 stayers and 158 returners who provided information on all variables that are used in the analysis. In Table 2 we present the means of the variables across the two groups, along with indications of statistically significant differences.

It can be seen from the table that the two groups are quite similar. The returners are more likely to be living in Dublin and less likely to work in education. As regards age, education, labour market experience, gender and marital status, there are essentially no differences between returners and stayers. The variable of greatest interest is wage; here we find a difference between the two groups with the returners being paid about IRf150 more per month. This is a wage advantage of about 9 per cent and the difference is statistically significant at the 5 per cent level. Below, we will see if the difference remains when we control for a range of factors. One question that 
might arise from this observation is whether, a priori, returning migrants are more likely to overstate their earnings but we can see no reason why this might be so.

B efore proceeding to the regression analysis, we present some additional information on the returners. A number of questions were asked of migrants

Table 2: Descriptive Statistics on Returners and Stayers

\begin{tabular}{|c|c|c|c|c|}
\hline \multirow[b]{3}{*}{ Age (in years) } & \multicolumn{2}{|c|}{ Stayers } & \multirow{2}{*}{\multicolumn{2}{|c|}{$\begin{array}{c}\text { Returners } \\
\text { Mean Std. Deviation }\end{array}$}} \\
\hline & Mean St & td. Deviation & & \\
\hline & 28.32 & 2.76 & 28.19 & 2.0 \\
\hline Experience (in years) & 4.72 & 1.62 & 4.82 & 1.26 \\
\hline \multicolumn{5}{|l|}{ Education dummy variables } \\
\hline Certificate/diploma & 0.27 & 0.44 & 0.24 & 0.43 \\
\hline Bachelor Degree & 0.26 & 0.44 & 0.32 & 0.47 \\
\hline \multicolumn{5}{|l|}{ Masters Degree or } \\
\hline Equivalent & 0.43 & 0.50 & 0.38 & 0.49 \\
\hline Doctorate & 0.037 & 0.19 & 0.063 & 0.20 \\
\hline Dublin & $0.37^{* *}$ & 0.48 & 0.49 & 0.50 \\
\hline Male & 0.51 & 0.50 & 0.6 & 0.50 \\
\hline $\begin{array}{ll}\text { Partner } & 0.64\end{array}$ & 0.48 & 0.70 & 0.46 & \\
\hline \multicolumn{5}{|l|}{ Sectoral dummy variables } \\
\hline Computers & 0.07 & 0.26 & 0.095 & 0.29 \\
\hline Manufacturing & 0.20 & 0.40 & 0.24 & 0.43 \\
\hline $\begin{array}{l}\text { Real Estate, renting } \\
\text { and business }\end{array}$ & 0.14 & 0.35 & 0.17 & 0.38 \\
\hline Education & $0.19 * *$ & 0.39 & 0.10 & 0.30 \\
\hline Health & 0.05 & 0.21 & 0.06 & 0.24 \\
\hline Other sectors & 0.35 & 0.48 & 0.33 & 0.47 \\
\hline \multicolumn{5}{|l|}{ Gross monthly } \\
\hline wage (IRf) & $1,675^{*}$ & 699 & 1,825 & 794 \\
\hline & $N=670$ & & $N=158$ & \\
\hline
\end{tabular}


concerning their reasons for and feelings about migration. In Tables 3 to 5, we show the distribution of responses to these questions. Table 3 contains the distribution of responses to a question about how the returners felt when they were first leaving I reland. The most striking point from the table is that almost three-quarters were either looking forward to going or delighted to leave.

The reasons for the optimism can be seen more clearly in Table 4 where the distribution of responses to a question on the reasons for leaving are Table 3: How the Returners Felt about Leaving I reland

\begin{tabular}{lcc}
\hline \hline & Frequency & Per Cent \\
\hline Very U pset - Sad & 6 & 4.0 \\
Upset - Sad But Not Badly & 14 & 9.3 \\
Not Too Bad & 19 & 12.7 \\
Looking Forward to Going & 90 & 60.0 \\
Delighted to Leave & 21 & 14.0 \\
Total & 150 & 100 \\
& & \\
\hline \hline
\end{tabular}

Table 4: Reasons for Leaving

\begin{tabular}{lcr}
\hline \hline & Frequency & Per Cent \\
\hline To Get a J ob & 22 & 13.9 \\
To Get a Better J ob & 19 & 12.0 \\
To Get Better Wages & 9 & 5.7 \\
Tax Rated Too High & 4 & 2.5 \\
To Continue Further Education & 15 & 9.5 \\
Family Was Leaving - Left With Them & 2 & 1.3 \\
Adventure, See the World & 66 & 41.8 \\
Other & 21 & 13.2 \\
Total & 158 & 100.0 \\
\hline \hline
\end{tabular}


Table 5: Reasons for Returning

\begin{tabular}{lcr}
\hline \hline & Frequency & Per Cent \\
\hline & 5 & \\
Became Unemployed Abroad & 45 & 3.2 \\
Returned to a J ob in Ireland & 3 & 28.5 \\
Accompanied Spouse & 6 & 1.9 \\
Preferred to Raise Child in Ireland & 11 & 3.8 \\
Other Family Commitments & 47 & 7.0 \\
Preferred Lifestyle & 41 & 29.7 \\
Other Reason & 158 & 26.0 \\
Total & & 100.0 \\
\end{tabular}

presented. Only 13.9 per cent answered that they left to get a job, implying that most emigration had a voluntary dimension. Of particular interest in this table is the fact that over 40 per cent left for reasons of "adventure". Referring back to the discussion above, we take this as evidence that emigration for some has a consumption element that might impact upon wages on return to I reland. The absence (or at least lesser importance) of labour market considerations are also seen in Table 5 which presents the distribution of reasons for returning. Over a quarter of the returners said that their main reason for returning was because they preferred the lifestyle in I reland. While it is almost certainly the case that this lifestyle response is conditional on a threshold level of success in the Irish labour market, it nonetheless points to considerations other than solely labour market outcomes.

We now move onto our regression analysis of the wage differential between stayers and returners. In order to consider the relative wages of the two groups, we estimate standard OLS wage equations in which the standard controls are included and the dependent variable is the log of the monthly wage. I nitially, we include a dummy variable indicating if the individual is a returner or a stayer; in later regressions we differentiate between different lengths of time away and different types of returners. At this point we are taking a simple approach to the issue and in particular are ignoring selection effects; however, we do consider the selection issue below.

The first results are shown in the second col umn of Table 6, where the full sample (i.e. both males and females) are included and the dependent variable 
Table 6: Wage Equations with Returner Dummy Variable (Dependent variable: log of monthly wage)

\begin{tabular}{|c|c|c|c|c|c|c|}
\hline & \multicolumn{2}{|c|}{ All; N = 828} & \multicolumn{2}{|c|}{ Men; $N=412$} & \multicolumn{2}{|c|}{ Women; $N=416$} \\
\hline & B & t-stat & B & t-stat & B & t-stat \\
\hline Experience & 0.07 & 8.24 & 0.08 & 6.07 & 0.06 & 5.08 \\
\hline \multicolumn{7}{|l|}{ Bachelor } \\
\hline $\begin{array}{l}\text { Masters Degree } \\
\text { or Equivalent }\end{array}$ & 0.30 & 9.33 & 0.28 & 5.26 & 0.32 & 8.42 \\
\hline Doctorate & 0.51 & 7.55 & 0.46 & 4.65 & 0.56 & 6.04 \\
\hline Dublin & 0.10 & 3.96 & 0.06 & 1.32 & 0.15 & 4.73 \\
\hline Male & 0.16 & 6.23 & & & & \\
\hline Partner & -0.05 & -1.79 & -0.08 & -1.75 & -0.03 & -0.82 \\
\hline Returner & 0.05 & 1.48 & 0.10 & 1.98 & -0.01 & -0.31 \\
\hline \multirow[t]{2}{*}{ Constant } & 6.71 & 115.90 & 6.88 & 78.76 & 6.73 & 94.27 \\
\hline & \multicolumn{2}{|c|}{ Adj- R2 $=0.22$} & \multicolumn{2}{|c|}{ Adj- R2 $=0.18$} & \multicolumn{2}{|c|}{ Adj- $R 2=0.23$} \\
\hline
\end{tabular}

Specification Tests

Full sample

Ramsey RESET test, $F(3,816)=0.54$, Prob $>F=0.6567$

Cook-Weisberg test for heteroscedasticity, chi2(1) $=0.16$, Prob $>$ chi $2=0.6846$

Shapiro-Wilk W test for normal data, $z=7.335, \operatorname{Pr}>z=0.0000$

Males

Ramsey RESET test, $F(3,401)=0.99$, Prob $>F=0.3991$

Cook-Weisberg test for heteroscedasticity, chi2(1) $=1.92$, Prob $>$ chi $2=0.1658$

Shapiro-Wilk W test for normal data, $z=5.703, \operatorname{Pr}>z=0.0000$

Females

Ramsey RESET test, $F(3,405)=1.14$, Prob $>F=0.3336$

Cook-Weisberg test for heteroscedasticity, chi2(1) $=0.03$, Prob $>$ chi $2=0.8524$

Shapiro-Wilk W test for normal data, $z=5.391, \operatorname{Pr}>z=0.0000$ 
is the logarithm of the gross monthly wage. Before looking at the returner wage premium we will consider the other variables in the regression. Experience, which is measured in years, is positive and significant, as would be expected. Typically, the square of experience is also included but this is unnecessary here because of the nature of the sample. As all individuals graduated six years prior to the survey, the length of their labour market experiences are short and similar. The next three variables represent education levels, with certificates/diplomas being the omitted category. Again, the coefficients are as expected. Those working in Dublin earn 10 per cent more and men earn 16 per cent more than women. The variable "partner" is one if the individual is living with a partner and zero otherwise; although the coefficient is negative, it is insignificant.

While this pattern of coefficients is broadly repeated in the separate regressions for men and women, the coefficients of Dublin differ significantly across the genders. What is surprising is that the Dublin-based premium is not statistically significant for the men in the sample. In samples of all employees, as opposed to just graduate employees, a premium for men would typically be observed (see, for example, Barrett et al., 2000). It would appear that graduate earnings for men are more equal across the country than the earnings of others. What is also surprising is that the men in this sample with partners earn less than men without partners, although this is only marginally significant. The point estimate for women with partners is also negative but it is not significant in any of the models. ${ }^{2}$

For the full sample, returners are found to have a wage premium of 5 per cent relative to stayers but the point estimate is statistically insignificant. By looking at the results for men and women separately, we can see that the full sample result hides an interesting distinction between men and women. For men, the returner wage premium is 10 per cent and is statistically significant. In contrast, women returners do not enjoy a wage premium.

A range of specification tests were run on the regressions in Table 6, and on the regressions in Tables 7-9. As the pattern of results of these tests are identical across all regressions, the following discussion for Table 6 applies for the later tables. We initially ran RESET tests for functional form but found no evidence of omitted variables in any of the regressions (test statistics are shown with the tables). We then tested for heteroscedasticity and again found no evidence of this difficulty. As a final specification test, we ran Shapiro-Wilk tests for non-normality and did find evidence of non-normality.

As is well known (e.g. Spanos, 1986, p. 447), relaxing normality assumptions when homoscedasticity can be retained does not upset most of

2. The difference between the coefficients of partner for men and women is never significant. 
Table 7: Wage Equations with TimeAway (Dependent variable: log of monthly wage)

\begin{tabular}{|c|c|c|c|c|c|c|c|}
\hline & & \multicolumn{2}{|c|}{ All; $N=828$} & \multicolumn{2}{|c|}{ Men; $N=412$} & \multicolumn{2}{|c|}{ Women; $N=416$} \\
\hline & & B & t-stat & B & t-stat & B & t-stat \\
\hline Experience & & 0.07 & 8.21 & 0.08 & 6.10 & 0.06 & 5.11 \\
\hline Bachelor Degre & & 0.28 & 8.10 & 0.26 & 5.05 & 0.31 & 6.59 \\
\hline \multicolumn{8}{|l|}{ Masters Degree } \\
\hline or Equivalent & & 0.30 & 9.26 & 0.27 & 5.16 & 0.32 & 8.43 \\
\hline Doctorate & & 0.51 & 7.47 & 0.45 & 4.54 & 0.56 & 6.02 \\
\hline Dublin & & 0.10 & 4.01 & 0.06 & 1.41 & 0.15 & 4.63 \\
\hline Male & & 0.16 & 6.15 & & & & \\
\hline Partner & -0.05 & -1.76 & -0.08 & -1.67 & -0.03 & -0.84 & \\
\hline Time away & & 0.02 & 1.61 & 0.03 & 1.44 & 0.01 & 0.51 \\
\hline \multirow[t]{2}{*}{ Constant } & & 6.72 & 116.18 & 6.89 & 78.53 & 6.73 & 94.67 \\
\hline & & Adj- R & $2=0.22$ & Adj- R & $2=0.18$ & Adj- R2 & $=0.23$ \\
\hline
\end{tabular}

Note: Time away for stayers is equal to zero.

Specification Tests

Full sample

Ramsey RESET test, $\mathrm{F}(3,817)=0.74$, Prob $>\mathrm{F}=0.531$

Cook-Weisberg test for heteroscedasticity, chi2(1) $=0.31$, Prob $>$ chi $2=0.5795$

Shapiro-Wilk W test for normal data, $z=7.337, \operatorname{Pr}>z=0.0000$

Males

Ramsey RESET test, $F(3,401)=1.31$, Prob $>F=0.2698$

Cook-Weisberg test for heteroscedasticity, chi2(1) $=1.65$, Prob $>$ chi $2=0.1983$

Shapiro-Wilk W test for normal data, $z=5.667, \operatorname{Pr}>z=0.0000$

Females

Ramsey RESET test, $F(3,406)=1.69$, Prob $>F=0.1692$

Cook-Weisberg test for heteroscedasticity, chi2(1) $=0.08$, Prob $>$ chi2 $=0.7842$

Shapiro-Wilk W test for normal data, $z=5.433, \operatorname{Pr}>z=0.0000$ 
the desirable OLS criteria. Coefficient and variance estimates are still unbiased and consistent, although more efficient estimates taking account of the non-normality are theoretically obtainable. Usually, the practical difficulty with non-normality is that the assumed t-distributions of coefficient test criteria are no longer exact in small samples, although they are still asymptotically justified. With over 800 observations, we can appeal to asymptotic theory with considerable confidence. Furthermore, it is the relatively large number of observations that has made the test of normality sensitive enough to display the result it did. The degree of deviation from normality is actually quite slight, as demonstrated by a histogram (not shown, but available from the authors). For these reasons, the results of the tests are quite credible. ${ }^{3}$

In Table 7, we move from using a dummy variable to indicate returners. Instead we use a measure of length of time away and set it equal to zero for stayers. As the questionnaire included a question on when the individuals first emigrated and when they returned it is possible to construct such a variable. We have to concede that in cases where multiple moves were taken, our measure will overstate the length of time away and so measurement error is possible.

The time away variable is measured in years so the coefficient point estimate for the full sample in Table 7 indicates that returners earn almost 2 per cent more relative to stayers for each additional year they were away. However, this estimate is insignificant, as are the corresponding estimates for men and women. It could be that the insignificance is a result of measurement error, as discussed in the preceding paragraph. If a number of graduates moved multiple times they will not have had a chance to move upwards along a wage/tenure profile even though the measure of time away in our data would incorrectly suggest that they did have the time.

Our next set of estimates is presented in Table 8. Given that Dustmann (1997) discusses return migration in terms of it representing an investment in human capital, it is of interest to consider if the wage premium differs according to the initial reason for emigration. Referring back to Table 4, we can see that the first five reasons can be viewed as indicating that emigration was for career advancement purposes. As such we group the returners who gave this response into a category who "left for labour reasons"; the other group, which is made up of those who left with family or for adventure, is then

defined as those who left for "non-labour reasons". In the regressions the coefficients on these dummy variables are measured with respect to stayers.

3. We are grateful to Denis Conniffe for advice on this point. 
It might be argued that combining the five reasons into a single variable is invalid if there is a belief, for example, that migrating "to get a job" is

Table 8: Wage Equations with Reasons for Leaving (Dependent variable: log of monthly wage)

\begin{tabular}{|c|c|c|c|c|c|c|}
\hline & \multicolumn{2}{|c|}{ All; $N=828$} & \multicolumn{2}{|c|}{ Men; N =412 } & \multicolumn{2}{|c|}{ Women; $N=416$} \\
\hline & B & t-stat & B & t-stat & B & t-stat \\
\hline \multirow{3}{*}{$\begin{array}{l}\text { Experience } \\
\text { Bachelor Degree } \\
\text { Masters Degree } \\
\text { or Equivalent }\end{array}$} & 0.07 & 8.22 & 0.08 & 6.15 & 0.06 & 5.09 \\
\hline & 0.28 & 8.15 & 0.26 & 5.15 & 0.31 & 6.61 \\
\hline & 0.30 & 9.29 & 0.28 & 5.25 & 0.32 & 8.42 \\
\hline Doctorate & 0.51 & 7.45 & 0.45 & 4.55 & 0.56 & 6.04 \\
\hline $\begin{array}{l}\text { Dublin } \\
\text { Male }\end{array}$ & 0.10 & 3.96 & 0.05 & 1.29 & 0.15 & 4.71 \\
\hline $\begin{array}{l}\text { Male } \\
\text { Partner }\end{array}$ & $\begin{array}{l}0.16 \\
-1.79\end{array}$ & $\begin{array}{l}6.08 \\
-0.08\end{array}$ & -1.74 & -0.03 & & \\
\hline $\begin{array}{l}\text { Left for } \\
\text { labour reason }\end{array}$ & \multicolumn{5}{|c|}{ Left for } & -0.24 \\
\hline $\begin{array}{l}\text { Left for } \\
\text { other reason } \\
\text { Constant }\end{array}$ & $\begin{array}{l}0.01 \\
6.71\end{array}$ & $\begin{array}{r}0.13 \\
115.90\end{array}$ & $\begin{array}{l}0.002 \\
6.88\end{array}$ & $\begin{array}{r}0.03 \\
78.76\end{array}$ & $\begin{array}{r}-0.01 \\
6.73\end{array}$ & $\begin{array}{l}-0.24 \\
93.85\end{array}$ \\
\hline Constant & \multicolumn{2}{|c|}{ Adj- R2 $=0.22$} & \multicolumn{2}{|c|}{ Adj- R2 $=0.18$} & \multicolumn{2}{|c|}{ Adj- R2 $=0.23$} \\
\hline
\end{tabular}

Note: Returning migrants categories are measured relative to stayers.

Specification Tests

Full sample

Ramsey RESET test, $F(3,816)=0.57$, Prob $>F=0.632$

Cook-Weisberg test for heteroscedasticity, chi2(1) $=0.14$, Prob $>$ chi $2=0.71$

Shapiro-Wilk W test for normal data, $z=7.366, \mathrm{Pr}>\mathrm{z}=0.0000$

Males

Ramsey RESET test, $F(3,400)=1.07$, Prob $>F=0.361$

Cook-Weisberg test for heteroscedasticity, chi2(1) $=1.89$, Prob $>$ chi $2=0.1687$

Shapiro-Wilk W test for normal data, $z=5.727, \operatorname{Pr}>z=0.0000$

Females

Ramsey RESET test, $\mathrm{F}(3,405)=1.13$, Prob $>F=0.3376$

Cook-Weisberg test for heteroscedasticity, chi2(1) $=0.03$, Prob $>$ chi $2=0.8601$

Shapiro-Wilk W test for normal data, $z=5.409, \operatorname{Pr}>z=0.0000$ 
qualitatively different from migrating "to get a better job". In truth, there is a degree of arbitrariness in the combination we chose but we believe it to make sense, especially when compared with the contrast category. That category is largely made up of those who left for reasons of adventure and this seems to us to differ qualitatively from the first five reasons. If the concern over amalgamating the first five reasons relates to possible differences in the human capital across individuals in the different cells, we would argue that controlling for human capital differences by including education and experience in the regressions counters this.

It can be seen in Table 8 that for the full sample there is evidence of a difference in the wage premium across the two groups of returners. While those who left for non-labour reasons earn the same as stayers, the wage advantage for the labour-related migrants is 8 per cent (as the p-value is .054, we take this as being significant). The gap is particularly large in the case of men; the wage advantage for men who migrated for labour reasons is 15 per cent. For women we find no difference between the two types of migrants, who in turn earn the same as women who stayed in I reland. For men, this would appear to indicate that the wage advantage is restricted to those who had explicit human capital motives for going. The question arises of why the female experience should differ from the male experience and we return to this below.

Our next regressions are shown Table 9 in which we introduce the sector in which the individuals work. Our primary reason for doing this is to see if the premium is related solely to a particular sector, namely computers. As this sector has been growing particularly strongly and skill shortages are believed to have lead to large wage rises, we wanted to see if the premium was simply the result of a large inflow of computer scientists. Once again, the returner categories are measured relative to all stayers.

Looking initially at the "all" column in Table 9 we see that although those working in computers have the largest wage advantage (the point estimate is not significant, however), those in manufacturing also enjoy a wage premium. In general, little of statistical significance emerges from this set of regressions. This is likely to be because of the small number of observation in the sectoral cells. The important point is that high wages in the computer sector do not seem to be driving our results.

We ran an additional set of regressions, aimed at establishing whether the returner wage premium was the result of a selection process. It could be that 
Table 9: Wage Equations with Sectors (Dependent variable: log of monthly wage)

\begin{tabular}{|c|c|c|c|c|c|c|}
\hline & \multicolumn{2}{|c|}{ All; $N=828$} & \multicolumn{2}{|c|}{ Men; N = 412} & \multicolumn{2}{|c|}{ Women; $\mathrm{N}=416$} \\
\hline & B & t-stat & B & t-stat & B & t-stat \\
\hline Experience & 0.07 & 8.25 & 0.08 & 6.14 & 0.06 & 5.18 \\
\hline \multirow{2}{*}{$\begin{array}{c}\text { Bachelor Degree } \\
\text { Masters Degree } \\
\text { or Equivalent }\end{array}$} & 0.28 & 8.08 & 0.26 & 5.03 & 0.31 & 6.44 \\
\hline & 0.30 & 9.48 & 0.28 & 5.36 & 0.33 & 8.45 \\
\hline Doctorate & 0.54 & 7.79 & 0.50 & 4.95 & .58 & 6.10 \\
\hline \multirow{3}{*}{$\begin{array}{l}\text { Dublin } \\
\text { Male } \\
\text { Partner } \quad-0.05\end{array}$} & 0.11 & & 0.06 & 1.40 & 0.15 & 4.54 \\
\hline & 0.15 & 5.92 & & & & \\
\hline & -1.87 & -0.08 & -1.87 & -0.03 & & \\
\hline \multirow{2}{*}{$\begin{array}{l}\text { R-computer } \\
\text { R-manufacturing }\end{array}$} & 0.16 & & 0.1 & 0.7 & & 1.70 \\
\hline & 0.13 & 2.16 & 0.13 & 1.56 & 0.0 & 1.06 \\
\hline R-Real estate etc. & -0.02 & -0.27 & -0.03 & -0.23 & -0.04 & -0.45 \\
\hline R-education & -0.16 & -1.68 & -0.27 & -1.13 & -0.15 & -1.61 \\
\hline R-health & 0.09 & 0.78 & 0.40 & 1.00 & 0.06 & 0.51 \\
\hline \multirow{3}{*}{$\begin{array}{l}\text { R-other } \\
\text { Constant }\end{array}$} & 0.04 & 0.80 & 0.15 & 1.84 & -0.07 & -1.01 \\
\hline & 6.71 & 115.39 & 6.88 & 78.28 & 6.73 & 93.73 \\
\hline & Adj- R2 & $=0.22$ & Adj- R2 & $=0.18$ & Adj- & $=0.24$ \\
\hline
\end{tabular}

Note: R-(sector) indicates returning migrants in each sector; stayers are the omitted catergory.

Specification Tests

Full sample

Ramsey RESET test, $F(3,811)=0.57$, Prob $>F=0.6356$

Cook-Weisberg test for heteroscedasticity, chi $2(1)=0.00$, Prob $>$ chi $2=0.9902$ Shapiro-Wilk W test for normal data, $z=7.351, \mathrm{Pr}>\mathrm{z}=0.0000$

Males

Ramsey RESET test, $\mathrm{F}(3,396)=0.58$, Prob $>\mathrm{F}=0.6289$

Cook-Weisberg test for heteroscedasticity, chi2(1) $=2.63$, Prob $>$ chi $2=0.1047$

Shapiro-Wilk W test for normal data, $z=5.734$, $\operatorname{Pr}>z=0.0000$

Females

Ramsey RESET test, $F(3,400)=2.48$, Prob $>F=0.0608$

Cook-Weisberg test for heteroscedasticity, chi2 $(1)=0.00$, Prob $>$ chi $2=0.9468$

Shapiro-Wilk W test for normal data, $z=5.314$, $\operatorname{Pr}>z=0.0000$ 
more able individuals migrate and return, and so would be observed to earn more whether they had migrated or not. We estimated a Heckman selection correction model in which we used the unemployment rate in each individual's county of residence in 1992 (i.e. the time the individuals were graduating) as a predictor of migration that would not affect the individuals' wages in 1998. As the coefficients on the lambda terms in the wage regressions were insignificant, we could conclude that selectivity was not driving our results but we are reluctant to overstate the point. Our identifying restriction is weak so we cannot be confident of having successfully controlled for selection. Clearly, more powerful identifying restrictions would be desirable but our data do not include such variables and it is difficult to obtain them from other sources. Hence, we must remain cautious on this point.

\section{DIFFERENCES BY GENDER}

Our analysis has uncovered differences in migration outcomes for men and women. In particular, the differences by gender in the coefficient estimates for "return" in Table 6 and "left for labour reasons" in Table 8 are statistically significant. B efore concluding, we will look again at the migration motives of the men and women in the sample to see if they help explain the observed patterns.

We should first point out that it is not a complete surprise that these differences emerged. Mincer (1978) developed a model in which migration decisions are made by families and not by individuals. In such a setting, migration occurs if there is a positive net gain to the family, even if one member suffers a net loss. As long as those gaining through migration can compensate anyone who loses, the family will find it optimal to migrate. Those suffering loses are called "tied migrants" by Mincer and empirical work has shown women more likely to be tied migrants than men (Sandell, 1977). If such a process is at work among the graduates in our sample, it could be that women do not reap the benefit of working away because they move at a time that is sub-optimal for them as an individual yet optimal in a family sense.

In order to see if there is any evidence of this type of process underlying our results, we went back to Tables 4 and 5 on migration motives and looked at the reasons for leaving and returning by gender. As regards leaving, there did appear to be differences in the pattern of motivation. Over half the men said they left for labour reasons while a third left for adventure; the exact opposite pattern arises for women. The distributions of reasons for returning are more similar, with one notable exception. While 8.2 per cent of men returned for what can generally be labelled "family reasons", 16.5 per cent of 
women stated this as their reason for returning.

The biggest difference between men and women arose with regard to the wage premium for those who left for labour-related reasons. For this reason we also looked at the motivations for leaving and returning for this group only. Very little difference is seen in the distributions of reasons across men and women falling into this cell. While this would appear to reduce the likelihood that a Mincer-type process is at work, we would suggest that it might still hold. While someone may state that their reason for returning was getting a job in I reland, this may be a primary reason. However, secondary factors may be at work and if these factors, such as family considerations, differ across the genders they may explain the lack of a wage premium for women.

One additional piece of analysis that we conducted on this point was to run a regression for women in which we included an interaction term for returners with partners. The result was to produce a coefficient for women returners without partners of 0.035 and a corresponding coefficient for women with partners of -0.07 . N either of these coefficients are significant and neither is the difference between them. However, as the cells get smaller achieving significance is more difficult so we would argue that this result is at least suggestive of a possible Mincer process.

\section{CONCLUSION}

Although Dustmann (1997) and Co, Gang and Yun (2000) hypothesise that return migrants will earn more than non-migrants due to human capital accumulation, we have pointed out that there are reasons to believe that the positive wage premium could exist for other reasons, or alternatively that returners could earn relatively less. Our empirical analysis has shown that among graduates of I rish colleges, returning males do indeed earn more than males who stayed in I reland although no effect is found for returning women. Given our alternative explanations for the wage premium the question arises of whether this is a human capital effect, a signalling effect or a self-selection effect.

Given our data, it is not possible to be definitive on this point. We have been able to show that the premium is restricted to those men who migrated for what we have described as labour market reasons but even this could be the result of the three possible explanations. Having said that, we would argue that the signalling story is the least likely explanation. Return migration could be the result of success or failure abroad. People may return because they know they are equipped with new skills or because they have done badly while away. Employers may not know precisely why someone is 
returning and so it seems unlikely that they would offer a 15 per cent wage premium on the basis of an uncertain signal. Even though our test for selfselection was weak, we found no evidence for selection. For these reasons our preferred explanation is the human capital story although this requires further investigation.

If the human capital story is correct, these results have a number of implications. From a national labour market perspective, the return of people with high levels of education, as observed by Barrett and Trace (1998), is a benefit given the competitive requirements of a modern economy. That these highly educated people also appear to have accumulated additional human capital is a further benefit to the I rish economy. From a micro-perspective, the wage advantage enjoyed by returners points to the benefits that individuals can enjoy through working abroad at least for a period of time.

Finally, the different results for men and women suggest another source of difference in the labour market experiences of each. Drawing on Mincer's (1978) terminology, it could be that the women we observed are "tiedmigrants" in the sense that their moves are determined by family considerations, possibly as part of a family formation process. While this is likely to be a small component in overall differences in the earnings of men and women, it nonetheless points to another dimension of the gendered labour market roles.

\section{REFERENCES}

BARRETT, A., T. CALLAN (ed.), A. DORIS, D. O'NEILL, H. RUSSELL, O. SWEETMAN and J. MCBRIDE, 2000. How Unequal? Men and Women in the I rish Labour Market, General Research Series No. 176, Dublin: Oaktree Press in association with The Economic and Social Research Institute.

BARRETT, A. and F. TRACE, 1998, "Who Is Coming Back? The E ducational Profile of Returning Migrants in the 1990s", I rish Banking Review, Summer.

BORJ AS, G.J ., 1987. "Self-Selection and the Earnings of I mmigrants", American Economic Review, Vol. 77.

CENTRAL STATISTICS OFFICE, 1999. Population and Migration Estimates, Dublin: CSO.

CO, C.Y., I.N. GANG and M.-S. YUN, 2000. "Returns to Returning: Who Went Abroad and What Does It Matter?", J ournal of Population Economics, Vol. 13 No. 1. DUSTMANN, C., 1997. "Return Migration and the Optimal Migration Duration", mimeo, Department of Economics, University College London. 
GASH, V. and P.J . O'CONNELL, 2000. The I rish Graduate Labour Market: A Six Year Follow-up Survey of Third Level Graduates from 1992, Dublin:

The Economic and Social Research Institute.

HIGHER EDUCATION AUTHORITY, 1993. First Destinations of Award Recipients in Higher Education, Dublin: HEA.

HIGHER EDUCATION AUTHORITY, 1994. Report, Accounts (1991 and 1992) and Students Statistics $1990 / 1991$ and 1991/1992, Dublin: HEA.

MINCER, J ., 1978. "Family Migration Decisions", J ournal of Political Economy Vol. 86.

NATIONAL ECONOMIC AND SOCIAL COUNCIL, 1991. The Economic and Social Implications of Emigration, prepared for the Council by $\mathrm{J} . \mathrm{J}$. Sexton, B.M. Walsh, D.F. Hannan and D. McMahon, Dublin: National Economic and Social Council.

Ó GRÁDA, C. and B.M. WALSH, 1994. "The Economic Effects of Emigration: I reland" in B.J. Asch (ed.), Emigration and I ts Effects on the Sending Country, Santa Monica, California: Rand.

SANDELL, S., 1977. "Women and the E conomics of Family Migration", Review of Economics and Statistics, Vol. 59, pp. 406-414.

SPANOS, A., 1986. Statistical Foundations of Econometric Modelling, Cambridge: Cambridge University Press.

STARK, O., 1991, The Migration of Labour, Oxford: Basil Blackwell. 